\title{
PERAN VITAL BASYARNAS DALAM PENYELESAIAN SENGKETA BISNIS SYARIAH
}

\author{
Masyithah \\ Fakultas Syariah Instiitut Agama Islam (IAIN) Madura \\ Jl. Raya Panglegur No.Km. 4, Barat, Ceguk, Tlanakan, Kabupaten Pamekasan, \\ Jawa Timur69371| masyithahjakfar86@gmail.com \\ DOI: https://doi.org/10.35719/ijl.v3i2.129
}

\begin{abstract}
The emergence of Islamic financial institutions in Indonesia is good progress for the Muslim community. however, the demands of the system and its management also arise with its increasing development. Moreover, solving problems also suppresses the existence of institutions that can handle them. Arbitration that has been carried out by the Prophet, khulafaurrasyidin even in the dynasties that followed is an out of court dispute resolution that can be an option for businessmen. On the initiative of the MUI, by going through several processes, the National Sharia Arbitration Board was formed to resolve disputes between sharia business parties.

Keywords: Basyarnas, implementation, dispute, sharia business
\end{abstract}

Abstrak: Munculnya lembaga-lembaga keuangan syariah di Indonesia merupakan angin segar bagi masyarakat muslim, namun dengan demikian tuntutan atas sistem serta pengelolaannya juga timbul seiring dengan perkembangannya yang semakin menjamur. Lebih dari itu penyelesaian atas permasalahan yang terjadi juga menekan adanya lembaga yang bisa menangani. Arbitrase yang pada hakikinya sudah dilakukan pada masa Rasulullah, khulafaurrasyidin bahkan pada dinastidinasti setelahnya merupakan penyelesaian sengketa di luar pengadilan yang dapat dijadikan pilihan bagi pelaku bisnis. Atas prakarsa MUI dengan melewati beberapa proses Badan

\section{IJLIL: INDONESIAN JOURNAL OF LAW AND ISLAMIC LAW VOLUME 3 NOMOR 2 JULI-JDESEMBER 2021; ISSN 2721-5261 E-ISSN 2775-460X}


Masyithah

Arbitrase Syariah Nasional terbentuk guna menyelesaikan sengketa antara pihak-pihak pebisnis syariah.

Keywords: Basyarnas, implementasi, sengketa, bisnis syariah

\section{Pendahuluan}

Tanggal 1 November 1990 merupakan lahirnya Bank Muamalah Indonesia yang diprakarsai oleh Pemerintah, MUI dan ICMI. Sejak saat itu pula perkembangan lembaga keuangan syariah mengalami perkembangan yang sangat pesat mulai dari perbankan syariah, asuransi syariah dan BMT (Baitul Mal wa Tamwil). Hal ini juga terjadi pada sektorsektor usaha lainnya yang berbasis syariah atau lembagalembaga non Bank seperti hotel syariah, kolam renang syariah, multi level marketing syariah, reksadana syariah, obligasi syariah, asuransi syariah dan sebagainya. Animo masyarakat semakin tinggi dalam merespon eksistensi lembaga-lembaga dan usaha yang berasas syariah yang mengedapankan hukum bebas riba lebih-lebih setelah terjadinya huru hara ekonomi yang melikuidasi bank-bank besar pada pra dan pascareformasi. Dalam pelaksanaannya tentu terdapat beberapa ketentuan yang tertuang dalam Undang-undang yang beberapa kali mengalami perubahan karena acuannya pada surat earan Bank Indonesia, maka pada tanggal 21 Juli 2008 disahkanlah Undang-undang tentang 
Perbankan syariah. ${ }^{1}$ Dalam Undang-undang tersebut tampak bahwa terdapat dua sistem perbankan yang berlaku di Indonesia yaitu sistem perbankan konvensional yang memberlakukan bunga dalam operasionalnya dan perbankan syariah yang menjunjung hukum Islam yang bebas riba. Adapun kegiatan usaha yang dapat dilakukan oleh Bank syarian diatur dalam pasal 36 Bank Indonesia nomor $6 / 24 / \mathrm{PBI} / 2004^{2}$.

Data Bank Indonesia menunjukkan bahwa perbankan syariah mengalami perkembangan dan kemajuan yang sangat spektakuler pada tahun 2008. Hal ini bisa dilihat dari menjamurnya Bank-bank syariah di Indonesia. Belum lagi adanya hotel-hotel syariah, pegadaian syariah dsb. Perkembangan yang sangat signifikan ini juga diperkuat dengan data jumlah nasabah dan SDM yang terserap dalam lembaga-lembaga keuangan syariah tersebut. ${ }^{3}$

Berkembangnya lembaga-lembaga keuangan syariah tentunya akan berbanding lurus dengan jumlah transaksi

${ }^{1}$ Dewi Utami Sari, Penyelesaian Sengketa Perbankan Syariah di Indonesia

Al-Muqkidz : Jurnal Kajian Keislaman vol: 8 no. 2 (Mei-Agustus 2020), 157-158.

${ }^{2}$ Mardani, Penyelesaian Sengketa Bisnis Syariah, MIMBAR HUKUM Vol.22 No.2 Juni 2010. 298

3 Dewi Utami Sari, Penyelesaian Sengketa Perbankan Syariah di Indonesia

Al-Muqkidz : Jurnal Kajian Keislaman vol: 8 no. 2 (Mei-Agustus 2020), 157-158. 
yang terjadi di dalamnya dan dengan banyaknya transaksi yang terjadi, maka kemungkinan terjadinya perselisihan antara lembaga semakin berpeluang besar. Setiap hubungan dalam sebuah transaksi pasti mengharapkan terciptanya hubungan yang baik serta berkelanjutan. Sengketa tentunya tidak terjadi karena dapat menghancurkan hubungan bisnis. Untuk itu masing-masing pihak hendaknya mengantisipasi adanya sengketa yang mungkin terjadi di kemudian hari. ${ }^{4}$ Umumnya bisnis diawali dengan perjanjian ataupun kesepakatan antar pihak. Adanya cedera janji dapat menyebabkan timbulnya sengketa antara keduanya disebabkan tidak terpenuhinya faktor-faktor yang menjadi kesepakatan pada perjanjian awal. Di sengaja atau tidak, undang-undang tetap harus diberlakukan dan dipertanggungjawabkan.

Konflik akan berkembang saat salah satu pihak merasa dirugikan. Di Indonesia penegakan hukum pada prinsipnya berada dalam kekuasaan badan yudikatif oleh kekuasaan kehakiman sesuai yang tertuang dalam undang-undang 1945, maka yang mempunyai wewenang dalam memeriksa dan mengadili sengketa adalah badan peradilan yang berada di bawah kekuasaan kehakiman dan berpuncak pada Mahkamah

4 Bhismoadi Tri Wahyu Faizal, Menakar Urgensi Pengaturan Pelaksanaan Pembatalan Putusan Badan Arbitrase Syariah Nasiona (BASYARNAS). IJLIL, Vol. 1, No. 1, Desember 2019. 20 
Agung Republik Indonesia. Dengan demikian jelas bahwa peradilan adalah satu-satunya lembaga yang berwenang dalam menyelesaikan permasalahan sengketa, namun jika melihat pada pasal 1851, 1855 KUH Perdata, penjelasan pasal 3 UU No.14/1970 serta UU No. 30/1999 mengenai arbitrase dan alternatif penyelesaian sengketa, akan memungkinkan para pihak yang bersengketa untuk menyelesaikan sengketa di luar lembaga peradilan. Sehingga terdapat dua pilihan dalam penyelesaian sengketa yaitu dengan pengadilan melalui proses litigasi. Pengadilan dianggap sebuah solusi yang dapat menyelesaian sengketa sebagai the first and the last resort yang dapat memberikan keadilan kepada pihak yang bersengketa walau pada kenyataannya belum dapat merangkul kebutuhan masyarakat dalam penyelesaian sengketa dengan berbagai macam ketidakpuasan berupa biaya yang mahal, kurang responsif, lambat dalam penyelesaian, timbulnya permusuhan serta terjadinya berbagai pelanggaran. Fakta ini akan berpengaruh pada kelancaran jalannya bisnis. Dibutuhkan jalan keluar yang cepat, efektif dan efisien. Muncullah proses penyelesaian yang kedua di luar pengadilan (non litigasi) yang dianggap mampu memberikan solusi atas keresahan masyarakat dengan sifatnya yang menyelesaikan masalah secara komprehensif, lebih cepat dengan keputusan 
final dan tentunya tetap menjaga hubungan baik antara pihak-pihak yang bersengketa. ${ }^{5}$

Penyelesaian sengketa di luar pengadilan sering disebut dengan ADR (alternative dispute resolution). Hal ini sering diartikan sebagai alternative to litigation dan alternative to adjudication. Jika mengacu pada pengertian pertama, maka semua mekanisme di luar pengadilan termasuk arbitrase merupakan bagian dari ADR. Sedangkan jika mengacu pada pengertian kedua berarti yang dimaksud adalah penyelesaian yang sifatnya konsensus atau kooperatif seperti negosiasi, mediasi dan konsiliasi. Sedangkan arbitrase tidak termasuk pada ADR. Alternative to adjudication akan menghasilkan output berupa win-lose seperti yang terjadi di Amerika Serikat. Alternative to litigation akan menghasilkan win-win lose atau mutual acceptable solution. ${ }^{6}$

Negosiasi merupakan sebuah proses yang dilakukan oleh dua pihak dengan adanya kepentingan yang berbeda dengan membuat suatu persetujuan secara kompromis dan memberikan kelonggaran, dilakukan secara sederhana dan dengan persahabatan. Negosiasi memungkinkan pihak yang bersengketa tidak turun langsung dalam melakukan negosiasi, namun mengutus atau mewakilkannya pada seseorang yang

5 Nurul Ichsan, Penyelesaian Sengketa Perbankan Syariah di Indonesia. Ahkam: Vol. XV, No. 2, Juli 2015. 231-232

${ }^{6}$ Endrik Safudin, Alternatif Penyelesaian Sengketa dan Arbitrase, Malang: Intrans Publishing 2018. 13 
telah ditunjuk untuk melakukan kompromi dan memberikan kelonggaran demi tercapainya sebuah kesepakatan damai. Untuk mengikat kesepakatan damai tersebut kesepakatan damai dari negosiasi didaftarkan di pengadilan negeri dalam jangka waktu 30 hari terhitung setelah penandatanganan serta dilaksanakan 23dalam waktu 30 hari terhitung sejak pendaftarannya. ${ }^{7}$

Adapun karakteristik negosiasi antara lain adanya para pihak yang bersengketa, konflik atau sengketa di antara dua pihak, pertukaran atau penawaran kesepakatan, adanya pertemuan dua pihak secara langsung, berkaitan dengan masa yang akan datang serta tidak melibatkan orang ketiga. Adapun syarat-syaratnya adalah adanya i'tikad baik, komunikasi yang masih berjalan baik antara dua belah pihak, adanya rasa saling percaya, transparan atau terbuka serta adanya keseimbangan. ${ }^{8}$

Mediasi adalah proses penyelesaian sengketa di luar pengadilan di mana dalam prosesnya pihak yang bersengketa akan dibantu oleh mediator yang ditunjuk untuk membantu mereka guna mencapai kesepakatan atau kesepakatan terhadap seengketa yang dihadapi. Dalam hal ini mediator tidak memiliki wewenang dalam mengambil keputusan,

\footnotetext{
7 Maskufa, Peyelesaian Sengketa Perjanjian Syariah pada Lembaga Keuangan Syariah; Al-Iqtishad: Vol. V, No. 1, Januari 2013. 134 8 Endrik Safudin, Alternatif Penyelesaian Sengketa dan Arbitrase, Malang: Intrans Publishing 2018. 20-21.
} 
namun diserahkan kepada dua pihak yang bersengketa. Adapun karakteristik mediasi yaitu merupakan penylesaian sengketa di luar pengadilan, melibatkan mediator yang diterima oleh pihak yang bersengketa (mediator di sini hanya sebagai fasilitator dan tidak memiliki wewenang dalam mengambil keputusan), mediasi memiliki tujuan untuk mencapai kesepakatan tertulis yang diterima oleh pihak yang bersengketa. Sedangkan syarat-syarat mediasi adalah adanya i'tikad baik dari pihak yang bersengketa dalam menyelesaikan sengketa yang terjadi, perhatian terhadap hubungan baik di masa yang akan datang, kepentingan bersama untuk menyelesaikan sengketa secara cepat, singkat dan sederhana serta adanya kesamaan pandangan guna menghindari publikasi yang buruk yang disebabkan adanya sengketa. ${ }^{9}$

Konsiliasi merupakan penyesuaian pendapat dan penyelesaian sengketa dengan suasana persahabatan, dilakukan di pengadilan sebelum dimulainya persidangan utuk menghindari terjadinya proses litigasi. Konsiliasi dapat dilakukan di dalam atau di luar pengadilan. ${ }^{10}$

Karakteristik konsiliasi antara lain merupakan proses penyelesaian sengketa di luar pengadilan, konsiliator adalah pihak ketiga yang bersifat netral dan bertugas untuk

9 Endrik Safudin, Alternatif Penyelesaian Sengketa dan Arbitrase, Malang: Intrans Publishing 2018. 37-38.

${ }^{10}$ Maskufa, Peyelesaian Sengketa Perjanjian Syariah pada Lembaga Keuangan Syariah; Al-Iqtishad: Vol. V, No. 1, Januari 2013. 134 
membantu pihak yang bersengketa untuk menyelesaikan sengketa guna mencapai kesepakatan tertulis serta memiliki wewenang dalam mengusulkan pendapat dan saran-saran yang meliputi keuntungan dan kerugiannya dan merancang syarat-syarat kesepakatan antara dua pihak yang bersengketa, namun tidak berhak dalam mengambil keputusan. Syaratsyarat konsiliasi yaitu bahwa para pihak memiliki kekuatan tawar menawar yang sebanding, memiliki perhatian terhadap hubungan di masa yang akan datang, banyak persoalan yang memungkinkan terjadinya pertukaran, adanya kepentingan atau batas waktu untuk menyelesaikan, para pihak tidak memiliki permusuhan yang bersifat lama serta mendalam, jika para pihak mempunyai pengikut atau pendukung mereka tidak memiliki pengharapan yang banyak, namun dapat dikendalikan, menetapkan preseden atau mempertahankan suatu hak tidak lebih penting jika dibandingkan dengan penyelesaian permasalahan yang mendesak, para pihak berada dalam proses litigasi, maka kepentingan-kepentingan pelaku lainnya seperti pengacara dan penjamin tidak akan diberlakukan baik dibanding dengan proses ini."

Arbitrase adalah proses penyelesaian sengketa di mana pihak yang bersengketa menginginkan perkaranya diputus oleh juru pisah pilihan mereka yang bersifat netral.

${ }^{11}$ Endrik Safudin, Alternatif Penyelesaian Sengketa dan Arbitrase, Malang: Intrans Publishing 2018. 65-66 
Jadi dari awal mereka telahmenerima putusan yang bersifat final dan mengikat. Dijelaskan dalam U Nomor 30 tahun 1999 bahwa arbitrase merupakan proses penyelesaian sengketa di luar pengadilan yang didasarkan pada perjanjian tertulis arbitrase yang dibuat oleh pihak yang bersengketa. Dalam arbitrase pihak yang bersengketa memiliki kebebasan dalam menentukan atau memilih arbiter serta bebas menentukan hukum yang akan diterapkan untuk menyelesaikan sengketa yang terjadi.

Berdasarkan paparan di atas tampak bahwa arbitrase memiliki kelebihan jika dibandingkan dengan solusi yang ditawarkan oleh lembaga nonlitigasi lainnya sehingga arbitrase menjadi pilihan yang paling banyak diminati oleh para pebisnis dalam menyelesaikan sengketa.

\section{Pembahasan}

Hubungan antar manusia tidak selamanya akan memiliki kesamaan pandangan. Perbedaan silang pendapat wajar terjadi. Islam yang tidak hanya mengatur koneksi antara manusia dan Rabbnya juga mengambil peranan penting dalam hal ini. Karena jika tidak, kedamaian mustahil tercipta jika perselisihan tanpa solusi terutama dari segi religi yang perannya sangat urgen. Maka Rasulullah tidak hanya memikul amanah sebagai penyampai dakwah tentang Ilahiyah semata. 
Tapi juga mengatur berbagai aturan hidup dalam masyarakat termasuk di dalamnya solusi ketika terjadi sengketa.

Jaman Rasulullah sudah banyak timbul permasalahan yang ditangani oleh beliau sendiri. Seperti kasus perceraian, kasus warits, pembunuhan, perdagangan, dsb. Seiring meluasnya daerah kekuasaan Islam, maka beliau mengutus para hakim ke berbagai daerah guna mengatasi permasalahan atau sengketa yang terjadi di sana. Salah satu contohnya adlah ketika beliau mengutus Ali bin Abi Thalib untuk menyelesaikan permasalahan di Yaman. Upaya banding dan kasasi serta peninjauan kembali juga sudah terjadi di zaman Rasulullah di mana para pihak menyanggah keputusan Ali dan meminta banding kepada Rasulullah. Pada masa khulafaurrasyidin putusan hukum berasaskan pada tiga pilar yakni Al-Qur'an, sunnah dan ijmak para sahabat. Di masa khulafaurrasyidin pada masa Umar bin Khattab, para hakim diangkat dengan kewenangan wilayah dan menurut materi perkara. Di masa ini juga terjadi pemisahan antara lembaga eksekutif dan yudikatif. Lembaga peradilan juga mulai diadakan pada masa Utsman bin Affan.

Pada masa umayyah para hakim di ibu kota diangkat oleh pemerintah pusat. Sedangkan di wilayah daerah, hakim diangkat oleh penguasa daerah. Sedangkan di masa Abbasiyyah dengan munculnya permasalahan yang semakin beragam dan munculnya perbedaaan madzhab antara yang 
Masyithah

memiliki perkara dengan hakim, maka ditulislah pedoman yang berlaku pada negara mengangkat dan memecat qadhi serta meninjau kembali putusan yang telah diputuskan. Pada masa itu perkara peradilan dilaksanakan di majlis-majlis yang telah ditentukan, maka tidak dibenarkan jika dilaksanakan selain di tempat tersebut, namun di masa ini juga terdapat pula lembaga penyelesaian sengketa di luar pengadilan yakni hakam atau tahkim, wilayah al-hisbah dan wilâyah almazhâlim.

Secara garis besar dapat digambarkan sebagai berikut: ${ }^{12}$

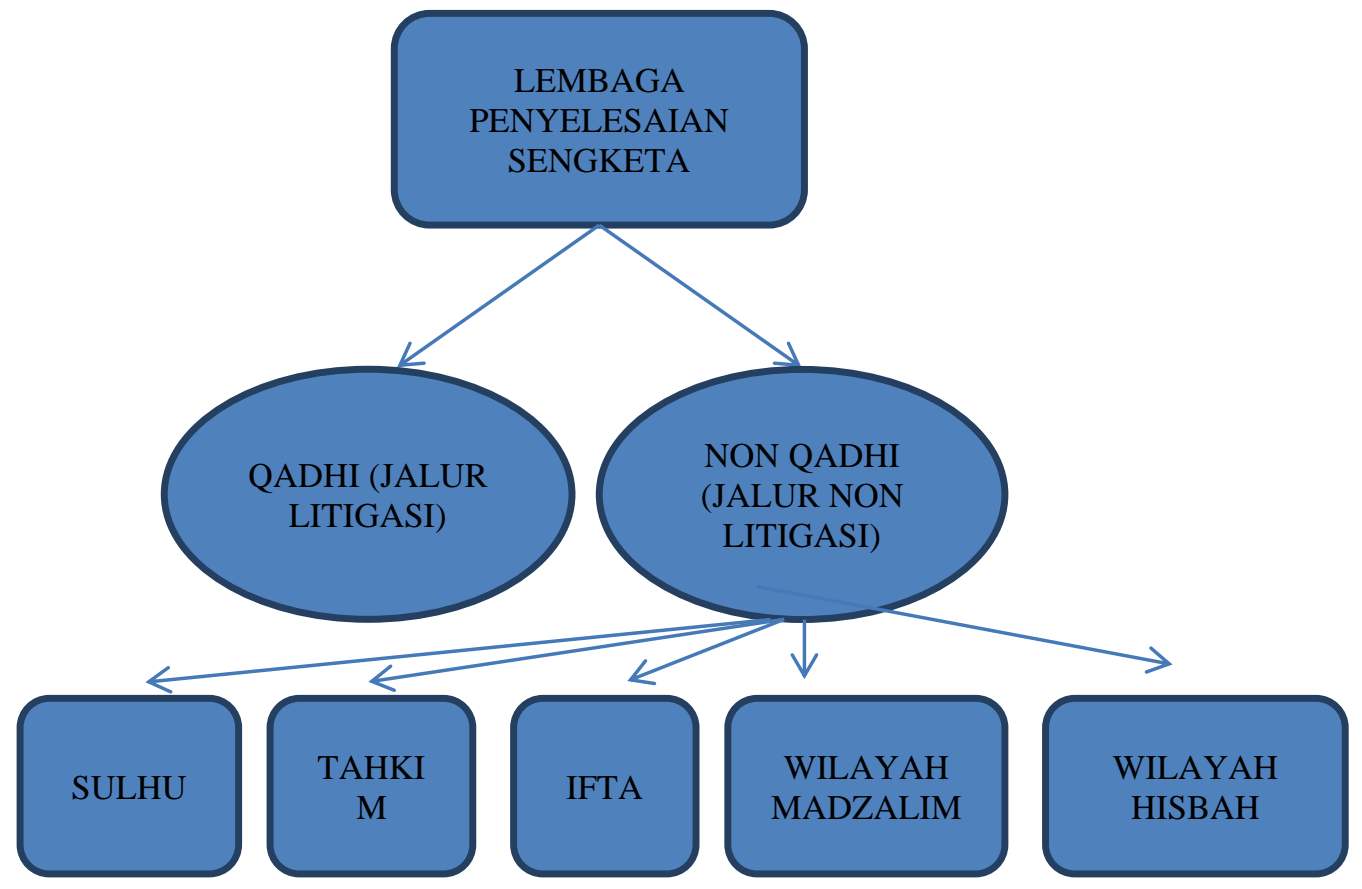

${ }^{12}$ Maskufa, Penyelesaian Sengketa Perjanjian Syariah pada Lembaga Keuangan Syariah. Al-Iqtishad: Vol. V, No. 1, Januari 2013. 119-122. 
Demikian lembaga litigasi dan nonlitigasi sebagai lembaga yang mengatasi permasalahan sengketa telah ada sejak zaman Rasulullah. Di Indonesia sendiri terdapat dua badan arbitrase, yaitu Badan Arbitrase Nasional Indonesia dan Badan Arbitrase Syariah Nasional. Basyarnas sebagai lembaga permanen yang didirikan oleh Majelis Ulama Indonesia pada tanggal 21 oktober $1993^{13}$. Berfungsi menyelesaikan kemungkinan terjadi sengketa muamalat yang timbul dalam hubungan perdagangan, industri, keuangan, jasa. Basyarnas merupakan wujud arbitrase Islam yang pertama kali muncul di Indonesia guna memenuhi kebutuhan masyarakat Islam dalam menyelesaikan sengketa bisnis syariah. ${ }^{14}$ Adanya badan arbitase syariah nasional di Indonesia tentunya memang sangat dibutuhkan meingingat menjamurnya lembagalembaga keuangan syariah yang melibatkan masyarakat muslim. Maka lembaga ini memungkinkan untuk menyelesaikan terjadinya sengketa di antara mereka khususnya sesama umat Islam dengan menjadikan hukum

13 Bhismoadi Tri Wahyu Faizal, Menakar Urgensi Pengaturan Pelaksanaan dan Pembatalan Putusan Badan Arbitrase Syariah Nasional (BASYARNAS). IJLIL: Indonesian Journal of Law and Islamic Law. Vol. 1, No. 1, Desember 2019. 20

${ }^{14}$ M. Nurul Irfan dkk, Peran Basyarnas dalam Penyelesaian Sengketa Ekonomi Syariah (Studi Pandangan Pelaku Ekonomi Syariah di Jakarta). AL-Manahij Vol. XI No. 2, Desember 2017. 145 
Islam sebagai dasarnya. ${ }^{15}$ Pada tahun 1993 telah tercatat 14 kasus telah diatasi oleh Basyarnas. ${ }^{16}$ Hal ini membuktikan kepercayaan masyarakat terhadapa lembaga ini dalam menyelesaikan sengketa.

Pendirian lembaga ini awalnya dikaitkan dengan berdirinya Bank Muamalat Indonesia dan Bank perkreditan Rakyat Syariah. Lembaga Arbitrase Syariah merupakan penyelesaian sengketa secara syariah antara kedua belah pihak di jalur pengendalian untuk mencapai kesepakatan masalah ketika upaya mufakat tidak tercapai. Disamping itu badan ini dapat memberikan suatu rekomendasi atau pendapat hukum, yaitu pendapat yang mengikat adanya suatu persoalan tetentu yang berkenaan dengan pelaksanaan perjanjian atas permintaan para pihak yang mengadakan perjanjian untuk diselesaikan. Apabila jalur arbitrase tidak dapat menyelesaikan perselihan, maka lembaga peradilan adalah jalan terakhir sebagai pemutus perkara tersebut. Hakim harus memperhatian rujukan yang berasal dari arbiter yang sebelumnya telah menangani kasus tersebut sebagai bahan pertimbanganuntuk menghindari lamanya proses penyelesaian.

15 Sanawiyah, Badan Arbitrase Syari'ah Nasional (BASYARNAS) Menyelesaikan Sengketa Secara Adil dan Cepat. Anterior Jurnal, Volume 12 Nomor 2, Juni 2013. 105

${ }^{16}$ M. Nurul Irfan dkk, Peran Basyarnas dalam Penyelesaian Sengketa Ekonomi Syariah (Studi Pandangan Pelaku Ekonomi Syariah di Jakarta). AL-Manahij Vol. XI No. 2, Desember 2017. 147 
Ketentuan badan arbitrase, keputusan pendamaian harus dijalankan dengan cara sukarela. Namun, sekiranya tidak dijalankan menurut ketentuan hukum yang ada di Indoensia, maka eksekusi akan dijalankan melalui Pengadilan Negeri setempat. Kewenangan Pengadilan Negeri tentunya sebatas dalam pelaksanaan eksekusi saja, tanpa harus mengolah atau memeriksa ulang kembali kasus yang sudah diselesaikan arbiter. Sistem hukum seperti ini sering menjadi perdebatan di kalangan pemerhati hukum, baik hukum konvensional maupun syariah dan cenderung dipandang sebagai salah satu kelemahan penyelesaian hukum melalui lembaga arbitrase.

Pandangan lain dalam realita yang ada Basyarnas sebagai lembaga arbitrase syariah di Indonesia saat ini belum maksimal dari aspek keberadaan dan perkembangannya seperti perkembangan lembaga keuaxngan syariah. Ia masih memerlukan peningkatan kualitas manajemen dan Sumber daya Manusia. Karena untuk dipercayai oleh masyarakat, lembaga ini harus mempunyai penampilan yang baik, sekretariat yang selalu dapat melayani pihak berkrisis. Di samping keadaan internal yang baik dan representatif, perlu juga didukung dengan pemberdayaan hukum (law enforcement) dari pemerintah, seperti tentang keputusan final dan mengikat (final and binding) dalam penyelesaian perkara. Pihak pengadilan Negeri juga dapat memaksa pihak yang 
tidak mau melaksanakan eksekusi dan menolak apabila pihak tersebut mengajukan kembali kasusnya ke pengadilan. Hal ini dapat menjadikan Basyarnas lebih berwibawa dan dianggap sangat diperlukan oleh pihak yang bersengketa.

Menangani sengketa, Basyarnas memiliki prosedur yang harus diikuti. Mulai dari permohonan untuk melaksanakan arbitrase, pemilihan arbiter, pemeriksaan, perdamaian, pembuktian dan saksi-saksi, berakhirnya pemeriksaan, pengambilan keputusan, pendaftaran putusan serta pelaksanaan putusan. ${ }^{17}$

\section{Penutup}

Berkembangnya lembaga keuangan syariah di Indonesia menunjukkan antusias masyarakat dalam berhijrah pada system yang berpondasikan Islam. Tumbuh kembang lembaga keuangan syariah berbanding lurus dengan kebutuhan lembaga-lembaga lain sebagai kebutuhan atas pemecahan permasalahan yang mungkin terjadi. Dengan itu Basyarnas hadir berperan sebagai lembaga yang menawarkan win-win solution dalam permasalahan lembaga keuangan syariah. Basyarnas sebagai lembaga nonlitigasi yang

\footnotetext{
${ }_{17}$ Andi Tenri Soraya dkk, Basyarnas Sebagai Lembaga Alternatif Penyelesaian Sengketa Bisnis Syariah. Analisis, Desember 2014, Vol.3 No.2. 176
} 
memiliki kelebihan-kelebihan dibandingkan jalur litigasi adalah alternatif yang dapat diambil guna menyelesaikan permasalahan dengan cara damai, efisien dan cepat.

\section{Daftar Pustaka}

Andi Tenri Soraya dkk, Basyarnas Sebagai Lembaga Alternatif Penyelesaian Sengketa Bisnis Syariah. Analisis, Desember 2014, Vol.3 No.2.

Bhismoadi Tri Wahyu Faizal, Menakar Urgensi Pengaturan Pelaksanaan Pembatalan Putusan Badan Arbitrase Syariah Nasiona (BASYARNAS). IJLIL, Vol. 1, No. 1, Desember 2019.

Dewi Utami Sari, Penyelesaian Sengketa Perbankan Syariah di Indonesia Al-Muqkidz : Jurnal Kajian Keislaman vol: 8 no. 2 (Mei-Agustus 2020).

Endrik Safudin, Alternatif Penyelesaian Sengketa dan Arbitrase, Malang: Intrans Publishing 2018.

Mardani, Penyelesaian Sengketa Bisnis Syariah, MIMBAR HUKUM Vol.22 No.2 Juni 2010.

Maskufa, Peyelesaian Sengketa Perjanjian Syariah pada Lembaga Keuangan Syariah; Al-Iqtishad: Vol. V, No. 1, Januari 2013.

M. Nurul Irfan dkk, Peran Basyarnas dalam Penyelesaian Sengketa Ekonomi Syariah (Studi Pandangan Pelaku Ekonomi Syariah di Jakarta). AL-Manahij Vol. XI No. 2, Desember 2017. 
Masyithah

Nurul Ichsan, Penyelesaian Sengketa Perbankan Syariah di Indonesia. Ahkam: Vol. XV, No. 2, Juli 2015.

Sanawiyah, Badan Arbitrase Syari'ah Nasional (BASYARNAS) Menyelesaikan Sengketa Secara Adil dan Cepat. Anterior Jurnal, Volume 12 Nomor 2, Juni 2013. 